\title{
TALHADO PARA A GRANDEZA
}

Maria do Rosário Caetano

Colunista do Jornal de Brasília

\section{O Brasil celebra este ano o sesquicentenário de nascimento de Castro Alves, que será lembrado em livros, filmes e relançamento de obras}

No próximo dia 14 de março, o País comemora o sesquicentenário de nascimento de Antônio Castro Alves (1847-1871), um dos poetas mais populares da história brasileira.

A Bahia, mais do que todos os territórios, dedicará festejos nobres a um de seus filhos mais ilustres. Mas os festejos de hoje lembram, apenas palidamente, os de 1947, data do centenário. Aí sim, o País festejou para valer. Castro Alves estava no auge, era adorado por multidões, recitado nas escolas e cantado em saraus.

Os tempos mudaram muito. Hoje, os ídolos populares se expressam em outras linguagens. Música, cinema e TV geram os grandes ídolos da juventude. Mesmo assim, São Paulo e Recife, onde estão as duas mais antigas faculdades de Direito do País, lembrarão o aluno brilhante, tribuno afoito e carismático. Brasília também estruturou programação significativa.

Os cineastas Nélson Pereira dos Santos e Sílvio Tendler prepararam dois filmes. O primeiro, ex-aluno da Faculdade de Direito do Largo de São Francisco, vai realizar um longa-metragem intitulado Castro Alves Guerra e Liberdade, sobre a agitada passagem do poeta por São Paulo e seu rumoroso caso com a atriz portuguesa, Eugênia Câmara. Tendler fará um documentário.

O diretor da Faculdade de Direito da USP, Álvaro Villaça Azevedo, lembra que a escola que notabilizou seus feitos na história político-institucional brasileira, e teve, além de Castro Alves, alunos brilhantes como Ruy Barbosa, Álvares de Azevedo, Fagundes Varella e o Barão do Rio Branco, estará comemorando, ao longo deste ano, além do sesquicentenário do poeta, seus 170 anos de fundação.

O professor Villaça lembra, ainda, que a Faculdade de Direito do Largo de São Francisco dará apoio total ao filme Guerra e Liberdade, pois "ele 
soma esforços de dois de nossos mais brilhantes alunos, Castro Alves e Nélson Pereira dos Santos" diz.

Antes de se transferir para a Faculdade de Direito de São Paulo, Castro Alves estudou na Faculdade de Direito do Recife, a mais antiga do País. Lá tornou-se amigo de Tobias Barreto, outro aluno brilhante. Travaram grande polêmica e dividiram a mocidade. Havia os tobinistas e os castristas. Os recifenses, como os paulistas, lembrarão o poeta dos escravos em sua passagem pela cidade.

Bahia Só nạ Bahia a festa será de arromba. Se não for, será por negligência da platéia, já que Consuelo Pondé, diretora do Instituto Histórico e Geográfico do Estado, comanda, incansável, a Comissão do Sesquicentenário. Como todo baiano, ela adora festa. Quando o motivo é Castro Alves, o ânimo de Consuelo chega ao paroxismo.

"Costumam dizer aqui na Bahia" - conta, zombeteira "que eu sou viúva de Castro Alves, tamanha é minha veneração por ele. Digo, sem nenhum constrangimento, que ele é o grande herói da nacionalidade brasileira. Um artista como poucos"

"Sabe" tieta a entusiasta admiradora "que eu tenho o nome artístico da última paixão dele, uma italiana (Agnese Trinci Murri) chamada, em seus versos, de Consuelo?" E prossegue: "temos arquivadas cartas nas quais ela jura nunca ter tido nada com Castro Alves. Mesmo assim, brincam comigo que tenho nome igual ao da última amada do poeta"

Depois das brincadeiras, Consuelo Pondé anuncia algumas das atrações dos festejos do Centenário. "Na Associação Comercial da Bahia, promoveremos sarau idêntico ao último freqüentado pelo poeta. Ele já estava muito doente e tivera o pé amputado (em julho de 1869), depois do tiro que levou numa caçada. Mesmo tuberculoso e com a saúde profundamente abalada, fez questão de comparecer a um encontro em benefício de crianças desvalidas em conseqüencia da Guerra Franco-Prussiana (de 1870). No evento, promovido pelo Comité du Pain, em fevereiro de 1871, ele declamou o poema Quem Dá ao Pobre Empresta a Deus. Foi sua última declamação pública"

O dia 14 começará com uma romaria a Cabaceiras, onde nasceu o poeta. No Parque Castro Alves será celebrada missa e a população passará o dia inteiro dedicada a atividades artísticas em memória do filho mais ilustre.

Em Salvador, na Praça Castro Alves, cantada por Caetano Veloso, os festejos serão múltiplos. "Queremos tudo ao ar livre" - avisa Consuelo - "para 
sermos coerentes com o poeta" Ele disse em um de seus poemas mais famosos que "a praça é do povo/como o céu é do condor". Por isto, o ator Jackson Costa, das novelas Renascer e Tocaia Grande, está escalado para declamar versos de Castro Alves, ao pé da estátua.

No mesmo local, serão lançados selo e cartão telefônico comemorativos ao sesquicentenário do vate baiano. A Odebrecht lançará, então, álbum com fotos e documentos que narram a (curta) história do autor de Os Escravos e do drama Gonzaga A Revolução de Minas. "Entre as raridades documentadas no livro" avisa Consuelo "estarão fotos de uma mecha de cabelo de Castro Alves, a mesa onde ele escreveu 'Espumas Flutuantes', reproduções em fac-símile de poemas manuscritos, e boa-parte de sua memória, que guardamos com zelo pretoriano"

A mecha de cabelo de Castro Alves mostra a que nível chegava a adoração popular ao poeta romântico. Antes de ser enterrado, houve quem achasse por bem guardar uma das mechas de seus belos e fartos cabelos. Aliás, um dos grandes atrativos de sua bela e invejada estampa. Homem de várias amantes, Castro Alves viveu com a atriz Eugênia Câmara, seu mais tórrido romance. Dez anos mais velha do que ele, Eugênia só cedeu depois de constatar a audácia dos versos enviados insistentemente pelo poeta. Os momentos vividos pelo casal são evocados por Castro Alves no poema Aves de Arribação, de 1870.

$\mathrm{Na}$ lista de convidados dos festejos baianos, está Jacy Faria Souto, de 80 anos, sobrinha-neta de Castro Alves. Ela esteve nos festejos de 1947 e garantiu deixar Petrópolis, onde vive, para ir a Salvador, festejar o tio ilustre.

\section{UM "CHE" GUEVARA ABOLICIONISTA}

\section{O cineasta Nélson Pereira dos Santos vai recriar uma parte da história do poeta} Castro Alves num épico histórico-literário-bélico

Nélson Pereira dos Santos vai imprimir no celulóide um sonho de dezoito anos. Ou seja, filmar parte da história do poeta Antônio de Castro Alves. Justo o período em que ele passou na Faculdade de Direito do Largo de São Francisco, em São Paulo. A mesma escola em que o cineasta realizou seu curso de advocacia. O filme será um longa-metragem de conteúdo histórico-literário-bélico. 
Em 1979, Nélson escreveu o roteiro do filme Castro Alves, registrando a passagem do poeta romântico baiano pela Faculdade de Direito do Largo de São Francisco, centro de São Paulo. Usou como base imensa pesquisa coordenada por Rudá de Andrade e levada a cabo por historiadores, professores de Letras e arquitetos da USP e Unicamp.

Rudá lembra bem de um dos estudos, que demandou viagens da equipe a estúdios de Los Angeles. "Nélson precisaria registrar a Faculdade de Direito no Largo de São Francisco, onde estudava Castro Alves, tal qual ela se apresentava em 1869. Ou seja, "cercada de riachos e lavadeiras, áreas verdes e nenhum prédio" Kitings estudou os efeitos especiais que permitiram a maquiagem cenográfica na São Paulo do final do século XX, já totalmente ocupada por prédios altos. "Hoje" lembra Rudá "com o desenvolvimento dos efeitos especiais, será bem menos complicado recriar a São Paulo de 152 anos atrás, que no começo dos anos 80" O desenhista Valandro Kitings já retomou seu trabalho na pré-produção de Castro Alves.

Retomada - O custo de produção de Castro Alves e o desejo de filmar Memórias do Cárcere, de Graciliano Ramos, adiaram o projeto por alguns anos. Na segunda metade dos anos 80 , Nélson sonhou em retomá-lo. Faltou quem ousasse financiar um filme histórico, orçado em US\$ 3,5 milhões.

O sonho tornou-se impossível na primeira metade dos anos 90. Com o Governo Collor, o cinema brasileiro ficou à deriva. Agora, com a nova Lei do Desenvolvimento do Audiovisual, o projeto do autor do clássico Vidas Secas ganhou fôlego. Produtores franceses e portugueses mostram imenso entusiasmo pela história do bardo romântico, poeta de extração huguiana e abolicionista militante. Além de amante da atriz Eugênia Câmara.

Antônio de Castro Alves foi uma espécie de "Che" Guevara da poesia. Morreu aos 24 anos, tísico e famoso. Belo, muito belo - dizia a lenda olhava-se no espelho e comentava: "senhoras mães, segurem suas filhas, Castro Alves vai sair às ruas"

A quem caberá a honra de interpretar o bardo? A Marcos Palmeira? Ou a Bruno Campos, um dos galãs de $O$ Quatrilho? Nélson diz preferir um desconhecido. Se o ator for nascido na Bahia, melhor ainda. Pretende escolhê-lo em testes públicos. Os candidatos deverão aparentar apenas 21 anos, idade de Castro Alves nos agitados tempos da Guerra do Paraguai. 
Orçamento Castro Alves, o filme, se passa na São Paulo do ano de 1868, quando o jovem baiano estudava Direito no Largo de São Francisco e vivia maritalmente com a atriz Eugênia Câmara, de 28 anos.

Além dele, destacam-se na trama cinco outros personagens de relevo: Ruy Barbosa, Joaquim Nabuco, José Bonifácio, o Moço, o poeta satírico e exescravo, Luís Gama, e Dionísio Cerqueira.

Nélson lembra que "os três primeiros tornaram-se muito famosos. Luís Gama e Dionísio, porém, foram quase esquecidos" Dionísio - acrescenta "tornou-se um militar de grande prestígio. Chegou ao generalato. É dele um dos livros que fundamentam as pesquisas do filme: 'Reminiscências da Guerra do Paraguai"'

O filme vai concentrar-se na ação dos jovens estudantes sendo Castro Alves, o foco das melhores atenções. E haverá espaço nobre para o amor do vate por Eugênia Câmara, atriz portuguesa que chegou à posteridade como "uma víbora" Nélson discorda e a define como "uma mulher fantástica, injustamente maltratada pelos biógrafos do poeta".

Na moralista sociedade brasileira do século passado, ela era a atriz de "vida fácil" mais velha e que mantinha um caso com um jovem poeta-e-estudante, sem estar unida a ele pelos laços do casamento. Os biógrafos, lembra Nélson, "culpam Eugênia pelo fato de Castro Alves levar vida boêmia e, principalmente, por beber muito. Acusam-na, com freqüência, de ser alcoólatra"

No filme, o enfoque será diferente. O cineasta avisa que "as pesquisas de nossa equipe comprovam que ela era uma mulher maravilhosa, uma intelectual e artista sensivel. Publicou livro de poemas, escrevia manifestos, planejava montagens teatrais ousadas e de temática brasileira. No tempo, histórico do filme, ela cuida da produção de Gonzaga, drama escrito por Castro Alves a partir do poeta inconfidente, Tomás Antônio Gonzaga"

Abolicionista No roteiro escrito por Nélson, a partir das pesquisas do grupo liberado por Rudá de Andrade, a luta pela Abolição da Escravatura e a Guerra do Paraguai terão lugar de destaque.

"Pretendo" avisa o cineasta "mostrar que a reação dos jovens abolicionistas à Guerra do Paraguai encontra perfeito parâmetro na reação dos jovens americanos à Guerra do Vietnã. Houve um movimento de massa liderado por estudantes brasileiros (entre eles Castro Alves) contra a Guerra da Tríplice 
Aliança (Brasil, Argentina, Uruguai) que quase dizimou o Paraguai de Solano Lopez"

No início do conflito, Castro Alves até escreveu poema para os jovens voluntários. Conclamava-os a trocar os livros pela espada e lembrava que houve quem usasse a espada como pena (Napoleão). Conclamava os jovens a ir para os campos de batalha, a partirem em busca da glória. Agindo assim, entrariam para a História. Ele mesmo não foi, pois já era tísico nesta época.

"Depois" pondera Nélson "a Guerra do Paraguai começou a se prolongar demais. Durou até 1871. Os intelectuais, artistas e cidadãos mais conscientes perceberam que o conflito servia de desculpa para adiar a solução de todos os problemas nacionais. Em especial, a escravidão. E Castro Alves e seus colegas mais atuantes eram abolicionistas. Mudaram de opinião"

Nélson está cuidando da captação de recursos orçamentários para seu épico castroalvino. As filmagens estão previstas para o final deste ano. No mais tardar, no primeiro semestre de 98 .

\section{AMANTE DA POESIA E DA POLÊMICA}

Antônio Frederico de Castro Alves nasceu no dia 14 de março de 1847, na Fazenda de Cabaceiras, no município de Muritiba, e faleceu em Salvador, Bahia, 24 anos depois (em 06 de julho de 1871), vitimado pelo mal do século, a tuberculose. Ao contrário de seus contemporâneos, Gonçalves Dias (1823-1864), José de Alencar (1829-1877), Machado de Assis (1839-1908), teve curto tempo para escrever sua obra.

Encontrava-se no auge de sua criatividade, quando a tísica, agravada por complicações de saúde advindas de traumática amputação do pé, ferido numa caçada e em ponto de gangrenar, o levou. Só um de seus livros Espumas Flutuantes - fora publicado. Mesmo assim, ele era um astro fulgurante. Seus recitais mobilizavam platéias imensas. Sua polêmica com Tobias Barreto sacudiu o Recife.

Depois da morte, a fama do bardo baiano só fez aumentar. Até os anos 60 deste século, ele era um ídolo nas escolas primária e secundária. Não havia grêmio escolar, que não promovesse recitais de $O$ Navio Negreiro. Castro Alves fascinava com seus excessos e sua paixão abolicionista. Tornou-se o símbolo dos que lutavam por causas humanitárias. A morte prematura o transformou num mártir. 
No segundo volume de Formação da Literatura Brasileira, Antonio Candido destaca: "Os seus (da obra de Castro Alves) aspectos positivo e negativo atingem o grau máximo na poesia abolicionista, onde a beleza lírica se alterna ou mistura ao mau gosto oratório e folhetinesco. Ela é o seu florão maior, não apenas por ser sua contribuição mais pessoal à nossa evolução poética, mas porque reúne os dois aspectos fundamentais da sua obra: poesia pública e poesia privada a sociedade e o eu"

A poesia negra do escritor é definida como verdadeiro milagre, uma vez que "o negro era a realidade degradante, sem categoria de arte, sem lenda heróica" O ensaio de Candido constitui leitura obrigatória para os admiradores do poeta baiano.

Castro Alves faleceu numa tarde ensolarada. E tinha razões de sobra para orgulhar-se. Nenhum poeta brasileiro, antes ou depois dele, causaria tanto furor em míseros 24 anos de vida. 



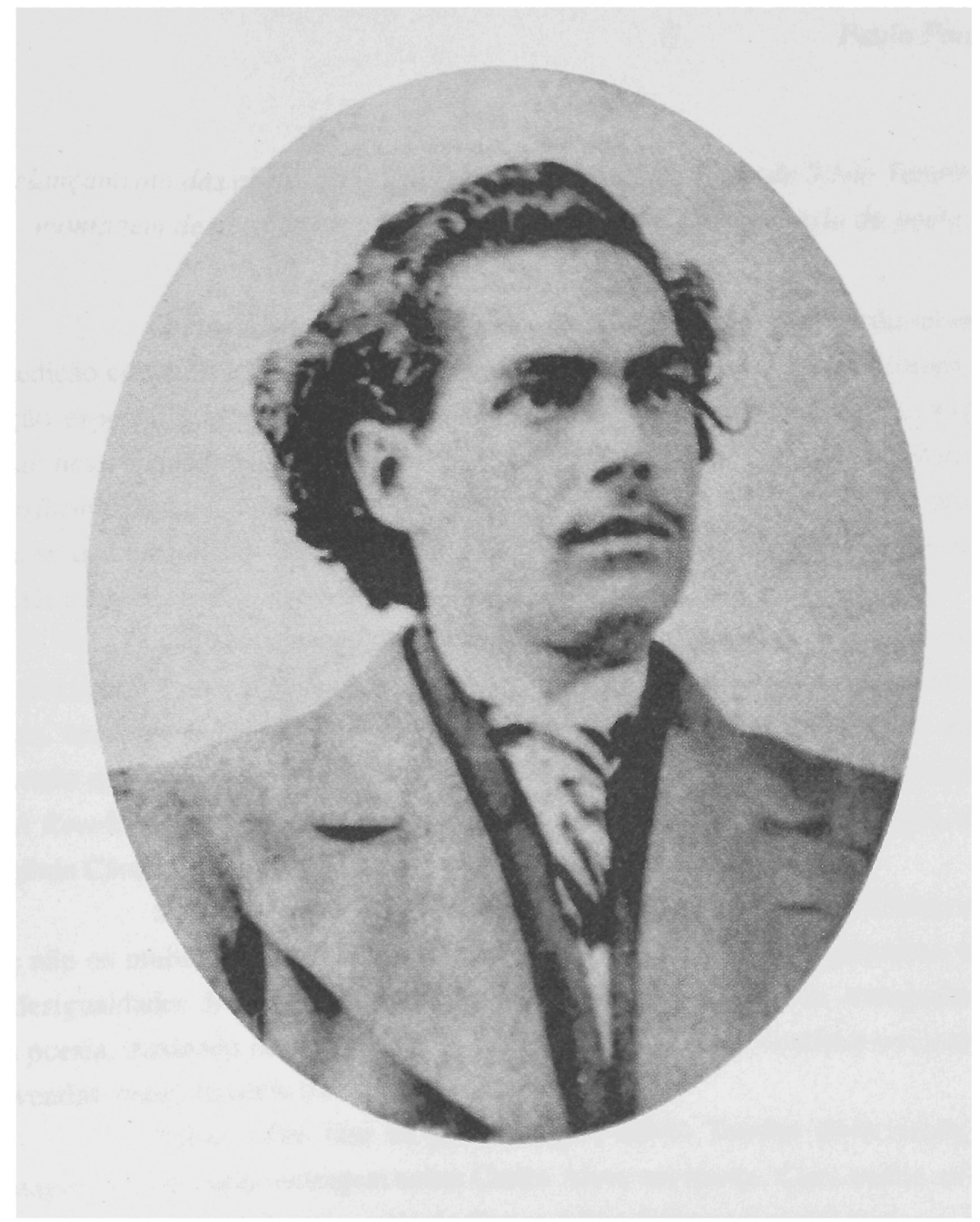

O autor de "Espumas Flutuantes" em uma de suas últimas fotos, em São Paulo 